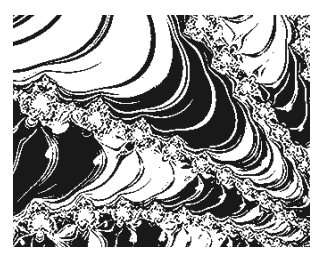

https://doi.org/10.5559/di.29.4.03

\title{
RESILIENCE IN SCHOOL CHILDREN - A MULTICULTURAL COMPARISON BETWEEN THREE COUNTRIES - CROATIA, SWEDEN AND PORTUGAL
}

Renata MILJEVIĆ-RIĐIČKI

University of Zagreb, Faculty of Teacher Education, Zagreb, Croatia

Celeste SIMÕES

University of Lisbon, Faculty of Human Kinetics, Cruz Quebrada, Portugal

Birgitta KIMBER

Umeå University, Department of Clinical Sciences, Umeå, Sweden

UDK: 316.73-057.874(497.5+485+469)

Izvorni znanstveni rad

Primlieno: 29. 1. 2019.

Culture and context are important for children's

development, affecting, inter alia, resilience. The main aim of our research was to find out if resilience among schoolaged children aged 10-12 differs between three countries Croatia, Sweden and Portugal. The participants were 750 pupils from Croatian, Swedish and Portuguese schools, $54.5 \%$ boys and $45.5 \%$ girls. The instrument used was the Child and Youth Resilience Measure-28 (CYRM-28).

Descriptive statistics were computed, and one-way between-groups ANOVAs were performed. The CYRM total score, as well as the item scores, were high. Both differences and similarities between the three countries were found. Sweden and Portugal share the highest number of non-significant comparisons, followed by Croatia and Sweden. Croatia and Portugal have the least between-pair similarities. The results are discussed in the context of countries' needs for education for resilience and application of the resilience curriculum (RESCUR).

Keywords: children, resilience, cross-cultural comparison, resilience curriculum

Renata Miljević-Riđički, Faculty of Teacher Education, University of Zagreb, Savska cesta 77, 10000 Zagreb, Croatia. E-mail: renata.miljevic@gmail.com 
Resilience can be defined as successful adaptation, such as through academic achievement, healthy relationships, and well-being, and the absence of internalizing or externalizing difficulties in the face of adversities, such as poverty, homelessness, and family instability and conflict (Masten, 2011).

Many researchers place resilience theory in an ecological context (Kolar, 2011), and often lean on Bronfenbrenner's ecological systems theory (1986), which emphasizes how important the microsystem, mesosystem, macrosystem, chronosystem and exosystem are in a child's life. The microsystem includes the people (family, friends) and institutions (school) closest to the child. The mesosystem shows that there are interrelations between parts of the microsystem; for example, school success may be influenced by the home climate, and partnership between teachers and parents is important. The exosystem includes extended family, neighbors, legal services, media, and the work of parents. The macrosystem represents attitudes and the ideologies of the culture, while the chronosystem is the time-based dimension, covering changes in context over time (Park \& Gauvain, 2009). Some coping mechanisms are clearly culturally determined. As Kuo (2010) points out, culture influences coping patterns across different groups (e.g., national and ethnic). For example, emotional expression in Chinese culture is not common, which is why Chinese people somatize more often than people in Western cultures. Suppression of emotions has a long tradition in Chinese society (Chen et al., 2005). Expression of emotions in a supportive environment is one of the basic coping mechanisms in adverse situations. A resilient person might use this mechanism for self-protection when facing stressful influences (Lahad, 1993). In European countries, expression of emotions has been encouraged (Cefai, Cavioni, et al., 2015). We tend to agree with Ungar, who says that "... aspects of resilience may either be active in nurturing and sustaining resilience, inactive in their contribution to resilience, or even threaten resilience when they conflict with other aspects of a child's life" (Ungar, 2008, p. 229). The example of different attitudes towards the expression of emotions (not recommended as a coping mechanism in China, but encouraged in European countries) prompts the idea that understanding one's own resilience has to encompass the culture and context of the individual (Ungar, 2008). What can also affect resilience is age. It has been noted in research with children between 5 and 17 years-old that resilience increases with age (Sun \& Stewart, 2007).

Multicultural comparisons of school children between European countries, in the case of this study, Croatia, Sweden and Portugal, may show that children differ with regard to 
DRUŠ. ISTRAŽ. ZAGREB GOD. 29 (2020), BR. 4, STR. 555-574

MILJEVIĆ-RIĐIČKI, R. ET AL.:

RESILIENCE IN SCHOOL... resilience according to the culture to which they belong. And, of course, there are cultural differences between all European countries. Ungar (2008, p. 225) offers a culturally and contextually sensitive definition of resilience: "In the context of exposure to significant adversity, whether psychological, environmental, or both, resilience is both the capacity of individuals to navigate their way to health-sustaining resources, including opportunities to experience feelings of well-being, and a condition of the individual's family, community and culture to provide these health resources and experiences in culturally meaningful ways". As we can see in Ungar's definition of resilience, the concepts of well-being and resilience overlap. Huppert and So (2013, p. 837) claim that they can identify "ten features of positive well-being. These combine feeling and functioning, i.e. hedonic and eudaimonic aspects of well-being: competence, emotional stability, engagement, meaning, optimism, positive emotion, positive relationships, resilience, self-esteem, vitality." In our work, we focus on one aspect of well-being, namely resilience.

Some sociologically oriented Portuguese researchers define resilience as "a complex and multilevel process through which societies, institutions and individuals respond to sudden and large-scale environmental, social and economic shocks" (Estevão et al., 2017, p. 21). They explain that Portugal, a geographically peripheral EU country, has had financial crises over the last decade that have had an impact on households, leading to an increased likelihood of poverty, an often-mentioned risk factor in relation to resilience (Estevão et al., 2017). Societal level factors interact with individual and social level factors (Kolar, 2011).

Croatia differs from the other countries in that it is the "youngest" country of the three, coming into existence only when former Yugoslavia broke up and becoming an independent state in 1991. The Croatian War of Independence, also called the Homeland War, was fought from 1991 to 1995 between Croat forces loyal to the government of Croatia which had declared independence from the Socialist Federal Republic of Yugoslavia (SFRJ) - and the Serb-controlled Yugoslav People's Army (JNA) and local Serb and Montenegrin forces. It was a defensive war, so UN Peace Forces were also involved. The war ended with Croatian victory, with Croatia gaining its independence and preserving its borders (Ravlić, 2019).

Although all European countries have cultural differences, Sweden, in the North of Europe, has been regarded as one of ten European countries with the best quality of life and happiness. According to recent statistics, Gross Domestic Product (GDP) per capita (US Dollars) per country was: 53.87 thou- 
DRUŠ. ISTRAŽ. ZAGREB GOD. 29 (2020), BR. 4, STR. 555-574

MILJEVIĆ-RIĐIČKI, R. ET AL.:

RESILIENCE IN SCHOOL... sand dollars in Sweden, 23.18 thousand dollars in Portugal, and 14.64 thousand dollars in Croatia (International Monetary Fund, 2018). Furthermore, the ranking of happiness (Helliwell et al., 2018) for 156 countries for the period 2015-2017 placed Sweden in 9th place, Portugal in 77th, and Croatia in 82 nd. The rankings have been explained by differences in social support, generosity, healthy life expectancy, perception of corruption, freedom to make life choices, and, as mentioned, GDP per capita. Sweden, the richest of the three countries, accepted 1748 thousand migrants in 2017 (17.6\% of the total population), Croatia 560 thousand (13.4\% of the total population), and Portugal 651 thousand $(8.5 \%$ is percentage of the total population) (United Nations, 2017).

The three countries involved in this research, and three more (Greece, Italy and Malta), joined together to make the first resilience curriculum for early years and primary schools in Europe.

RESCUR Surfing the Waves is designed to help European children build resilience skills to better cope with the difficulties they encounter. Funded by the EU, a framework has been developed by universities in these countries as a foundation for RESCUR. RESCUR Surfing the Waves consists of three manuals for different age groups (early years, early primary, and primary) and covers the following six themes:

1. Developing communication skills

2. Establishing and maintaining healthy relationships

3. Developing a growth mindset

4. Developing self-determination

5. Building on strengths

6. Turning challenges into opportunities (Cefai, Miljević-Riđički et al., 2015).

We call it a "European curriculum", but it might happen that a country adapts the content or educational practice and concentrates on some themes rather than others.

Given the importance of resilience for a positive and healthy development, especially in risk contexts, and the differences between European cultures, the aim of this study is to compare resilience between children in three countries: Croatia, Sweden and Portugal. The intention was to find out if resilience among school-aged children aged 10-12 differed between the countries, possibly according to their level of economic development. This age range has been chosen because it covers the (pre)transition period in life: transition occurring from middle childhood through adolescence. "In particular, understanding how individuals navigate developmental transitions is at the crux of understanding risk and resilience across 
DRUŠ. ISTRAŽ. ZAGREB GOD. 29 (2020), BR. 4, STR. 555-574

MILJEVIĆ-RIĐIČKI, R. ET AL.:

RESILIENCE IN SCHOOL.. the life span." (Graber \& Brooks-Gunn, 1996, p. 768). Prepuberty developmental experiences might affect resilience (Graber \& Brooks-Gunn, 1996).

A research question was posed: Are there differences in resilience between children aged 10-12 in three countries, Croatia, Portugal and Sweden?

\section{METHOD}

\section{Participants and data collection}

The sample consists of 750 pupils, $54.5 \%$ boys and $45.5 \%$ girls, from Croatian (57.2\% boys and $42.8 \%$ girls), Swedish $(50.8 \%$ boys and $49.2 \%$ girls) and Portuguese (55.5\% boys and $44.5 \%$ girls) schools (250 pupils from each country). The pupils were 10 to 12-year-olds from the 4th and 5th school grades in Croatia and Sweden, and 12 to 13-year-olds from the 5th and 6th grades in Portugal.

In Croatia, the data were collected in spring 2018 in schools from Varaždin and Zagreb County that did not, at that time, have any social and emotional learning (SEL) program. SEL programs aim to enhance social and affective competences in children "such as emotions recognition, stress management, empathy, problem solving, or decision-making skills" (Durlak et al., 2011, p. 13). The Croatian sample does not fully represent the Croatian population as a whole: $57 \%$ of the sample were boys and $43 \%$ were girls, compared to $51 \%$ and $49 \%$ in the population. Informed consent was obtained from parents and the ethical code for research was complied with.

In Sweden and Portugal, the data were collected through the anonymous self-report questionnaires that made up the data-collection part of a larger longitudinal RESCUR effectiveness study in Portugal and Sweden (Eriksson et al., 2018). RESCUR is a resilience curriculum for early and primary schools in Europe developed within an EU-funded three-year project (2012-2015). The data used in this study were collected at baseline, i.e., before any of the participants had been exposed to the intervention in schools.

In Sweden, active informed consent was given by parents and children. Data were collected from April until December 2017. The Swedish sample does not fully represent the Swedish population as a whole: $49 \%$ of the sample were boys and $51 \%$ were girls, compared to $51 \%$ and $49 \%$ in the population; $15 \%$ of the parents in the sample had a non-Swedish background, whereas the proportion for the population was $9 \%$.

In Portugal, as mentioned previously, the data were collected in schools participating in a RESCUR intervention, the 
DRUŠ. ISTRAŽ. ZAGREB GOD. 29 (2020), BR. 4, STR. 555-574

MILJEVIĆ-RIĐIČKI, R. ET AL.:

RESILIENCE IN SCHOOL... so-called RESCUR into Action Project, implemented in the Lisbon metropolitan area and Coimbra, and also at two other schools in the Lisbon metropolitan area; in the autumn of 2017, RESCUR into Action (RIA 2017-2018) became a national project (funded by Ciência Viva) that aimed to promote the development of resilience-related competencies in a classroom context in schools with migrant and/or refugee pupils through the implementation of the RESCUR curriculum (Cefai, Miljević-Riđički et al., 2015). The Portuguese sample does not fully represent the Portuguese school population as a whole: $55.5 \%$ of the sample were boys and $45.5 \%$ were girls, compared to $52 \%$ and $48 \%$ in the population; $6 \%$ of the children in the sample were non-Portuguese, whereas the proportion for the national school population is $4 \%$. Informed consent was obtained from parents to allow participation in the study, and the ethical code for research was complied with.

In all the countries, the questionnaires were administered in regular classes under the supervision of a teacher and took about 15-30 minutes to complete.

\section{Instrument}

1 See: http://cyrm. resilienceresearch.org/ how-to-use/
The instrument used in this study is the Child and Youth Resilience Measure-28 (CYRM-28), which is a 28-item measure that accounts for the individual, peer, family, and community resources involved in resilience processes (Ungar \& Liebenberg, 2011). CYRM-28 was developed by an international team of researchers from 11 countries who worked collaboratively to develop a culturally and contextually consisitative measures and a large sample. The results of this collaborative initiative show that CYRM-28 is a reliable measure of resilience across cultures. Nevertheless, the pattern of subscales can vary according to the respondents' culture and gender, and the social cohesion of their community. Reliability of the CYRM-28's three scales (Canadian sample), assessed using Cronbach's alpha, ranged from 0.79 to 0.83 , and the interclass correlation coefficients ranged from 0.58 to 0.77 . Subscale correlations ranged between 0.56 and 0.71 (Liebenberg et al., 2012).

Up to now (January 2020), the CYRM-28 instrument has been translated into more than 20 languages, including Croatian, Portuguese and Swedish. ${ }^{1}$

Validation has been effected for adolescents in Croatia and Portugal, and is being effected in Sweden during 2020. It has shown good psychometric properties so far - Croatia: Cronbach's alpha Global scale $=0.88$; Individual scale $=0.75$; Caregiver $=0.79$; Contextual $=0.76$; Portugal: Cronbach's alpha tent measure of youth resilience, using quantitative and qual- 
DRUŠ. ISTRAŽ. ZAGREB GOD. 29 (2020), BR. 4, STR. 555-574

MILJEVIĆ-RIĐIČKI, R. ET AL.:

RESILIENCE IN SCHOOL...
Global scale $=0.88$; Individual scale $=0.82$; Caregiver $=0.76$; Contextual $=0.72$. A confirmatory factorial analysis confirmed the original 3-scale and 8-subscale structure (Ferreira, 2014). All items are rated on a 5-point scale from $1=$ does not describe me at all to $5=$ describes me well, with higher scores indicating increased resilience processes. The CYRM-28's structure encompasses three scales: individual, relationship with primary caregiver, and context. The individual scale has three subscales: Personal Skills (5 items, e.g., "I cooperate with people around me"), Peer Support (2 items, e.g., "I feel supported by my friends"), and Social Skills (4 items, e.g., "I know how to behave in different social situations"). The caregiver scale has two subscales: Physical Caregiving (2 items, e.g., "My parent(s)/caregiver(s) watch me closely") and Psychological Caregiving (5 items, e.g., "My parent(s)/caregiver(s) know a lot about me"). The context scale has three subscales: Spiritual (3 items, e.g., "Spiritual beliefs are a source of strength for me"), Education (2 items, e.g., "Getting an education is important to me"), and Cultural (5 items, e.g. "I have people I look up to").

For the CYRM Global scale, Cronbach's alpha values for each of the scales ranged from 0.69 (Context scale) to 0.83 (Individual scale) for the whole sample (see Table 1). For each of the country samples, the same pattern was found, with higher Cronbach's alpha values for the individual scale and lower values for the Contextual scale. The values for each country ranged from 0.50 (Context) to 0.67 (Individual) in the Croatian sample, from 0.70 (Context) to 0.86 (Individual) in the Swedish sample, and from 0.73 (Context) to 0.85 (Individual) in the Portuguese sample. The inter-item correlation for the CYRM Global scale ranged from 0.34 to 0.69. Cronbach's alpha values for each of the subscales ranged from 0.38 (Caregiver - Physical Caregiving) to 0.80 (Individual - Peer Support) for the whole sample (see also Table 1). For each of the country samples, the values were lower, ranging from 0.20 (Context: Education) to 0.70 (Individual - Peer Support) in the Croatian sample, from 0.34 (Caregiver - Physical Caregiving) to 0.87 (Individual - Peer Support) in the Swedish sample, and from 0.27 (Caregiver - Physical Caregiving) to 0.81 (Individual - Peer Support) in the Portuguese sample. For the Swedish and Portuguese samples, two of the subscales show Cronbach's alphas below 0.50 (Caregiver - Physical Caregiving and Context - Education). For the Croatian sample, four subscales were below 0.50 (Individual - Personal Skills, Individual - Social Skills, Caregiver - Psychological Caregiving, 
DRUŠ. ISTRAŽ. ZAGREB GOD. 29 (2020), BR. 4, STR. 555-574

MILJEVIĆ-RIĐIČKI, R. ET AL.:

RESILIENCE IN SCHOOL...

(1) TABLE 1

Cronbach's alphas and inter-item correlations for the CYRM dimensions
Context - Education). The inter-item correlation for the subscales ranged from 0.15 to 0.78 .

Given the low Cronbach alpha values of some of the subscales, which indicate that they were not consistent, we opted to run a two-step analysis - first with the scores of the CYRM Global scale and the three item scales, second with the single items - to compare resilience levels between the three countries. Supporting this option was also the fact that four items were not used in the Swedish data collection (two items from the Context - Spiritual subscale, items 9 and 22, and two items from the Context - Cultural subscale, items 10 and 28), which prohibited the use of these two subscales from the very outset. The three scales were obtained by computing the total score of each one, as indicated by the original structure except for the Context scale (due to the missing items in the Swedish sample). In this exceptional case, the scale was computed from just the six items available for the three countries. Accordingly, the CYRM Global scale was computed from the 24 items available for all three countries rather than 28 items. The three scales showed a positive and strong correlation with each other, showing that higher levels of resources in one domain are associated with higher levels of resources in another domain. The correlation between the Individual and Context scales presents the highest value $(r=0.74, p<0.001)$. The correlation between the Individual and Caregiver scales $(r=0.64$, $p<0.001)$ and the correlation between the Caregiver and Context scales have very similar values $(r=0.63, p<0.001)$.

\begin{tabular}{|c|c|c|c|c|c|c|c|c|}
\hline \multirow[b]{2}{*}{ Scale/Subscale } & \multicolumn{2}{|c|}{ Croatia } & \multicolumn{2}{|c|}{ Sweden } & \multicolumn{2}{|c|}{ Portugal } & \multicolumn{2}{|c|}{ Global } \\
\hline & $\alpha$ & IICA & $\alpha$ & IICA & $\alpha$ & IICA & $\alpha$ & IICA \\
\hline Individual & 0.672 & 0.171 & 0.858 & 0.356 & 0.848 & 0.353 & 0.831 & 0.325 \\
\hline Personal Skills & 0.440 & 0.152 & 0.633 & 0.249 & 0.630 & 0.286 & 0.598 & 0.248 \\
\hline Peer Support & 0.701 & 0.540 & 0.873 & 0.775 & 0.805 & 0.676 & 0.801 & 0.668 \\
\hline Social Skills & 0.478 & 0.192 & 0.745 & 0.424 & 0.737 & 0.413 & 0.736 & 0.413 \\
\hline Caregiver & 0.580 & 0.183 & 0.819 & 0.403 & 0.784 & 0.358 & 0.757 & 0.328 \\
\hline Physical Caregivin & 0.540 & 0.373 & 0.337 & 0.209 & 0.266 & 0.164 & 0.377 & 0.235 \\
\hline Psychological Caregiving & 0.473 & 0.168 & 0.802 & 0.474 & 0.761 & 0.422 & 0.725 & 0.380 \\
\hline Context & 0.497 & 0.156 & 0.699 & 0.289 & 0.730 & 0.347 & 0.694 & 0.299 \\
\hline Spiritual & 0.541 & 0.221 & ---- & ---- & 0.537 & 0.262 & 0.606 & 0.331 \\
\hline Education & 0.204 & 0.128 & 0.433 & 0.307 & 0.481 & 0.349 & 0.405 & 0.283 \\
\hline Cultural & 0.521 & 0.178 & --- & ---- & 0.677 & 0.333 & 0.632 & 0.275 \\
\hline
\end{tabular}

$\alpha$-Cronbach's alpha; IICA - Inter-item Correlation Average

\section{Comparisons between the three countries}

Table 2 presents descriptive statistics for the CYRM Global scale, the three item scales, and the 24 specific items used in the study for the whole sample and all three countries. 
DRUŠ. ISTRAŽ. ZAGREB GOD. 29 (2020), BR. 4, STR. 555-574

MILJEVIĆ-RIĐIČKI, R.

ET AL.:

RESILIENCE IN SCHOOL...

\section{TABLE 2}

Mean values, standard deviations, maximum and minimum values on the CYRM Global scale, Individual scale, Caregiver scale, Context scale, and the 24 CYRM items used (with original CYRM numbering, omitting items $9,10,22$ and 28)
Scale/Items Mean SD Min. Max.

CYRM Global scale

Individual scale

Caregiver scale

Context scale

Item 1

I have people

I look up to

Item 2

I cooperate with

people around me

Item 3

Getting an education

is important to me

Item 4

I know how to behave in different social

situations

Item 5

My parent(s)/caregiver(s) watch me closely

Item 6

My parent(s)/caregiver(s) know a lot about me

Item 7

If I am hungry, there is enough to eat $\begin{array}{lllll}\text { Croatia } & 109.97 & 7.46 & 77.00 & 120.00\end{array}$

$\begin{array}{lllll}\text { Sweden } & 108.34 & 11.81 & 53.00 & 120.00\end{array}$

$\begin{array}{lllll}\text { Portugal } & 102.51 & 12.58 & 50.00 & 120.00\end{array}$

$\begin{array}{lllll}\text { Total } & 106.97 & 11.29 & 50.00 & 120.00\end{array}$

$\begin{array}{lllll}\text { Croatia } & 49.35 & 4.31 & 35.00 & 55.00\end{array}$

$\begin{array}{lllll}\text { Sweden } & 48.66 & 6.19 & 20.00 & 55.00\end{array}$

$\begin{array}{lllll}\text { Portugal } & 45.15 & 6.83 & 21.00 & 55.00\end{array}$

$\begin{array}{lllll}\text { Total } & 47.73 & 6.15 & 20.00 & 55.00\end{array}$

$\begin{array}{lllll}\text { Croatia } & 33.02 & 2.33 & 21.00 & 35.00\end{array}$

$\begin{array}{lllll}\text { Sweden } & 32.99 & 3.28 & 14.00 & 35.00\end{array}$

$\begin{array}{lllll}\text { Portugal } & 32.24 & 3.38 & 17.00 & 35.00\end{array}$

$\begin{array}{lllll}\text { Total } & 32.75 & 3.05 & 14.00 & 35.00\end{array}$

$\begin{array}{lllll}\text { Croatia } & 27.60 & 2.42 & 19.00 & 30.00\end{array}$

$\begin{array}{lllll}\text { Sweden } & 26.69 & 3.34 & 11.00 & 30.00\end{array}$

$\begin{array}{lllll}\text { Portugal } & 25.18 & 3.87 & 8.00 & 30.00\end{array}$

$\begin{array}{lllll}\text { Total } & 26.49 & 3.41 & 8.00 & 30.00\end{array}$

$\begin{array}{lllll}\text { Croatia } & 4.19 & 1.146 & 1 & 5\end{array}$

$\begin{array}{lllll}\text { Sweden } & 4.39 & 0.981 & 1 & 5\end{array}$

$\begin{array}{lllll}\text { Portugal } & 3.54 & 1.344 & 1 & 5\end{array}$

$\begin{array}{lllll}\text { Total } & 4.04 & 1.220 & 1 & 5\end{array}$

$\begin{array}{lllll}\text { Croatia } & 4.54 & 0.634 & 2 & 5\end{array}$

$\begin{array}{lllll}\text { Sweden } & 4.22 & 0.989 & 1 & 5\end{array}$

$\begin{array}{lllll}\text { Portugal } & 4.02 & 0.905 & 1 & 5\end{array}$

$\begin{array}{lllll}\text { Total } & 4.26 & 0.881 & 1 & 5\end{array}$

$\begin{array}{lllll}\text { Croatia } & 4.81 & 0.533 & 2 & 5\end{array}$

$\begin{array}{lllll}\text { Sweden } & 4.68 & 0.640 & 2 & 5\end{array}$

$\begin{array}{lllll}\text { Portugal } & 4.68 & 0.630 & 2 & 5\end{array}$

$\begin{array}{lllll}\text { Total } & 4.72 & 0.605 & 2 & 5\end{array}$

$\begin{array}{lllll}\text { Croatia } & 4.72 & 0.568 & 1 & 5\end{array}$

$\begin{array}{lllll}\text { Sweden } & 4.45 & 0.836 & 1 & 5\end{array}$

$\begin{array}{lllll}\text { Portugal } & 4.02 & 0.982 & 1 & 5\end{array}$

$\begin{array}{lllll}\text { Total } & 4.39 & 0.862 & 1 & 5\end{array}$

$\begin{array}{lllll}\text { Croatia } & 4.78 & 0.516 & 2 & 5\end{array}$

$\begin{array}{lllll}\text { Sweden } & 4.77 & 0.648 & 1 & 5\end{array}$

$\begin{array}{lllll}\text { Portugal } & 4.68 & 0.667 & 2 & 5\end{array}$

$\begin{array}{lllll}\text { Total } & 4.74 & 0.615 & 1 & 5\end{array}$

$\begin{array}{lllll}\text { Croatia } & 4.82 & 0.470 & 2 & 5\end{array}$

$\begin{array}{lllll}\text { Sweden } & 4.71 & 0.607 & 1 & 5\end{array}$

$\begin{array}{lllll}\text { Portugal } & 4.65 & 0.673 & 1 & 5\end{array}$

$\begin{array}{lllll}\text { Total } & 4.73 & 0.593 & 1 & 5\end{array}$

$\begin{array}{lllll}\text { Croatia } & 4.72 & 0.582 & 2 & 5\end{array}$

$\begin{array}{lllll}\text { Sweden } & 4.84 & 0.503 & 2 & 5\end{array}$

$\begin{array}{lllll}\text { Portugal } & 4.83 & 0.461 & 2 & 5\end{array}$

$\begin{array}{lllll}\text { Total } & 4.80 & 0.520 & 2 & 5\end{array}$


DRUŠ. ISTRAŽ ZAGREB

GOD. 29 (2020), BR. 4, STR. 555-574

MILJEVIĆ-RIĐIČKI, R.

ET AL.:

RESILIENCE IN SCHOOL...

TABLE 2

Continued from previous page
Scale/Items

Mean SD Min. Max.

Item 8
I try to finish
what I start

Item 11

People think that I am

fun to be with

Item 12

I talk to my family/

caregiver(s) about

how I feel

Item 13

I am able to solve problems without harming

myself or others

Item 14

I feel supported

by my friends

Item 15

I know where to go

in my community

to get help

Item 16

I feel I belong

at my school

Item 17

My family stands

by me during

difficult times

Item 18

My friends stand

by me during

difficult times

Item 19

I am treated fairly

in my community

Item 20 I have opportu-

nities to show others that

I am becoming an adult

and can act responsibly

\section{Croatia \\ Sweden \\ Portugal \\ Total}

Croatia

Sweden

Portugal

Total

Croatia

Sweden

Portugal

Total

Croatia

Sweden

Portugal

Total

Croatia

Sweden

Portugal

Total

Croatia

Sweden

Portugal

Total

Croatia

Sweden

Portugal

Total

Croatia

Sweden

Portugal

Total

Croatia

Sweden

Portugal

Total

Croatia

Sweden

Portugal

Total

Croatia

Sweden

Portugal

Total $\begin{array}{ll}4.47 & 0.718\end{array}$

$4.14 \quad 0.996$

$\begin{array}{ll}4.08 & 0.872\end{array}$

$4.23 \quad 0.884$

$\begin{array}{ll}4.23 & 0.920\end{array}$

$\begin{array}{lll}4.48 & 0.772\end{array}$

$\begin{array}{ll}3.97 & 0.911\end{array}$

$4.23 \quad 0.894$

$4.19 \quad 1.035$

$\begin{array}{ll}4.34 & 1.014\end{array}$

$4.14 \quad 1.094$

$4.22 \quad 1.050$

$\begin{array}{ll}3.88 & 1.401\end{array}$

\begin{tabular}{ll}
$4.37 \quad 0.945$ \\
\hline
\end{tabular}

$3.82 \quad 1.418$

$4.02 \quad 1.296$

$\begin{array}{ll}4.34 & 0.927\end{array}$

$4.45 \quad 0.953$

$4.22 \quad 0.975$

$4.34 \quad 0.955$

$\begin{array}{ll}4.71 & 0.613\end{array}$

$\begin{array}{ll}4.52 & 0.861\end{array}$

\begin{tabular}{ll}
$4.48 \quad 0.818$ \\
\hline
\end{tabular}

$4.57 \quad 0.777$

$\begin{array}{ll}4.54 & 0.887\end{array}$

$\begin{array}{ll}4.23 & 1.022\end{array}$

$\begin{array}{ll}4.29 & 0.981\end{array}$

$4.35 \quad 0.973$

$\begin{array}{ll}4.84 & 0.531\end{array}$

$4.73 \quad 0.680$

$4.71 \quad 0.650$

$4.76 \quad 0.625$

$4.34 \quad 0.932$

$4.42 \quad 0.942$

$4.09 \quad 1.036$

$4.28 \quad 0.980$

$\begin{array}{ll}4.42 & 0.725\end{array}$

$\begin{array}{ll}4.30 & 0.938\end{array}$

3.991 .016

$4.24 \quad 0.918$

$4.62 \quad 0.654$

$\begin{array}{ll}4.37 & 0.884\end{array}$

$3.95 \quad 1.021$

4.320 .909
5

5

5

5

5

5

5

5

5

5

5

5

5

5

5

5

5

5

5

5

5

5

5

5

5

5

5

5

5

5

5

5

5

5

5

5

5

5

5

5

Continued 
DRUŠ. ISTRAŽ. ZAGREB GOD. 29 (2020), BR. 4, STR. 555-574

MILJEVIĆ-RIĐIČKI, R.

ET AL.:

RESILIENCE IN SCHOOL...

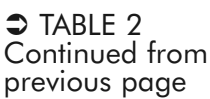

previous page
Scale/Items

Mean SD Min. Max.

Item 21

I am aware of my

own strengths

Item 23

I think it is important

to serve my community

Item 24

I feel safe when I am

with my family/care-

giver(s)

Item 25 I have opportunities to develop skills

that will be useful later

in life

Item 26

I enjoy my family's/care-

giver's cultural and

family traditions

Item 27

I enjoy my community's

traditions

$\begin{array}{lllll}\text { Croatia } & 4.73 & 0.656 & 1 & 5 \\ \text { Sweden } & 4.64 & 0.663 & 1 & 5 \\ \text { Portugal } & 4.27 & 0.880 & 1 & 5 \\ \text { Total } & 4.55 & 0.765 & 1 & 5 \\ \text { Croatia } & 4.90 & 0.314 & 3 & 5 \\ \text { Sweden } & 4.65 & 0.719 & 1 & 5 \\ \text { Portugal } & 4.45 & 0.797 & 1 & 5 \\ \text { Total } & 4.67 & 0.671 & 1 & 5 \\ \text { Croatia } & 4.92 & 0.320 & 2 & 5 \\ \text { Sweden } & 4.82 & 0.598 & 1 & 5 \\ \text { Portugal } & 4.78 & 0.583 & 2 & 5 \\ \text { Total } & 4.84 & 0.519 & 1 & 5 \\ \text { Croatia } & 4.76 & 0.487 & 3 & 5 \\ \text { Sweden } & 4.59 & 0.719 & 1 & 5 \\ \text { Portugal } & 4.24 & 0.875 & 1 & 5 \\ \text { Total } & 4.53 & 0.743 & 1 & 5 \\ \text { Croatia } & 4.74 & 0.665 & 1 & 5 \\ \text { Sweden } & 4.78 & 0.575 & 1 & 5 \\ \text { Portugal } & 4.45 & 0.817 & 1 & 5 \\ \text { Total } & 4.66 & 0.707 & 1 & 5 \\ \text { Croatia } & 4.74 & 0.659 & 1 & 5 \\ \text { Sweden } & 4.43 & 0.921 & 1 & 5 \\ \text { Portugal } & 4.23 & 1.021 & 1 & 5 \\ \text { Total } & 4.47 & 0.904 & 1 & 5\end{array}$

As mentioned previously, at the first step of analysis, a set of one-way between-groups ANOVAs were conducted to compare the resilience levels of the children from the three countries in the study, as measured by the Children and Youth Resilience Measure (CYRM). The robust test of equality of means (Brown-Forsythe test) was used when the test of homogeneity of variances was significant. To verify differences between the three countries, post-hoc comparisons employing the Scheffe or Dunnett T3 test, for items with equal variances assumed or not assumed, respectively, were used. The results show, for the CYRM Global scale, a significant difference, $F(2,643)=32.10, p<0.001$, between Croatia $(M=$ 109.97; $S D=7.46)$ and Portugal $(M=102.51 ; S D=12.58)$, and also between Sweden $(M=108.34 ; S D=11.81)$ and Portugal, but not between Croatia and Sweden. The effect size, calculated using eta squared, was medium $\left(\eta^{2}=0.08\right)$. This means that about $8 \%$ of the overall variance of resilience as measured by the CYRM scale is explained by the country variable.

Turning to the three item scales, the results showed significant differences between the three countries on the Context scale, $F(2,662)=34.96, p<0.001$, with Croatia having the highest means $(M=27.60 ; S D=2.42)$ and Portugal the low- 
DRUŠ. ISTRAŽ. ZAGREB GOD. 29 (2020), BR. 4, STR. 555-574

MILJEVIĆ-RIĐIČKI, R. ET AL.:

RESILIENCE IN SCHOOL...

(1) TABLE 3

$F$ tests and effect sizes est $(M=25.18 ; S D=3.87)$. For the Individual, $F(2,662)=36.33$, $p<0.001$, and Caregiver scales, $F(2,685)=5.23, p<0.001$, differences were found between Croatia and Portugal $(p<0.001)$, and also Sweden and Portugal $(p<0.001)$, but not between Croatia and Sweden (Individual, $p=0.425$; Caregiver, $p=0.386$ ). Again, Croatia presented the highest (Individual: $M=49.35$; $S D=4.31$; Caregiver: $M=33.02 ; S D=2.33$ ) and Portugal the lowest means (Individual: $M=45.15$; $S D=6.83$; Caregiver: $M=32.24 ; S D=3.38$ ). The effect size, calculated using eta squared, was medium for the Individual and Context scales $\left(\eta^{2}=0.09\right)$ but small for the Caregiver scale $\left(\eta^{2}=0.01\right)$. This means that about $9 \%$ of the variance in Individual and Context resilience is due to country, while only $1 \%$ of the variation in Caregiver resilience is explained by country.

\begin{tabular}{lrrr}
\hline & $F$ Test & Effect size \\
Items & $F \quad(d f)$ & $p$ & $\left(\eta^{2}\right)$ \\
\hline 1. I have people I look up to* & $36.47(2,700)$ & 0.000 & 0.09 \\
2. I cooperate with people around me* & $23.09(2,673)$ & 0.000 & 0.06 \\
3. Getting an education is important to me* & $3.77(2,729)$ & 0.024 & 0.00 \\
4. I know how to behave in different social situations* & $47.63(2,645)$ & 0.000 & 0.11 \\
5. My parent(s)/caregiver(s) watch me closely* & $2.13(2,714)$ & 0.129 & 0.01 \\
6. My parent(s)/caregiver(s) know a lot about me* & $5.27(2,694)$ & 0.003 & 0.01 \\
7. If I am hungry, there is enough to eat* & $4.36(2,719)$ & 0.013 & 0.01 \\
8. I try to finish what I start* & $14.12(2,701)$ & 0.000 & 0.04 \\
11. People think that I am fun to be with & $21.63(2,749)$ & 0.000 & 0.05 \\
12. I talk to my family/caregiver(s) about how I feel & $2.35(2,749)$ & 0.096 & 0.01 \\
13. I am able to solve problems without harming & & & \\
myself or others* & $14.15(2,677)$ & 0.000 & 0.04 \\
14. I feel supported by my friends & $3.71(2,749)$ & 0.025 & 0.01 \\
15. I know where to go in my community to get help* & $6.29(2,697)$ & 0.002 & 0.02 \\
16. I feel I belong at my school* & $7.49(2,737)$ & 0.000 & 0.02 \\
17. My family stands by me during difficult times* & $2.76(2,718)$ & 0.064 & 0.01 \\
18. My friends stand by me during difficult times & $7.84(2,749)$ & 0.000 & 0.02 \\
19. I am treated fairly in my community* & $15.04(2,698)$ & 0.000 & 0.04 \\
20. I have opportunities to show others that I am & & & \\
$\quad$ becoming an adult and can act responsibly* & $38.82(2,670)$ & 0.000 & 0.09 \\
21. I am aware of my own strengths* & $26.59(2,684)$ & 0.000 & 0.07 \\
23. I think it is important to serve my community* & $30.95(2,571)$ & 0.000 & 0.08 \\
24. I feel safe when I am with my family/caregiver(s)* & $5.00(2,627)$ & 0.007 & 0.01 \\
25. I have opportunities to develop skills that will be & & & \\
useful later in life* & $34.28(2,630)$ & 0.000 & 0.08 \\
26. I enjoy my family's/caregiver's cultural & & & \\
and family traditions* & $16.68(2,686)$ & 0.000 & 0.04 \\
27. I enjoy my community's traditions* & $21.57(2,671)$ & 0.000 & 0.05 \\
\hline
\end{tabular}

* Brown-Forsythe test

At the second step of the analysis, another set of one-way between-groups ANOVAs were conducted with the 24 items (Table 3). Despite reaching statistical significance in most cases, the effect size was small for the majority of items. Medium 
DRUŠ. ISTRAŽ. ZAGREB GOD. 29 (2020), BR. 4, STR. 555-574

MILJEVIĆ-RIĐIČKI, R.

ET AL.:

RESILIENCE IN SCHOOL...

() TABLE 4

Differences and

similarities between

the three countries

(based on post-hoc tests) effect sizes were verified for some items on the Individual and Contextual dimensions $\left(\eta^{2} \geq 0.06\right)$, namely "I cooperate with people around me", "I am aware of my own strengths" on the individual personal skills dimension, and "I know how to behave in different social situations", "I have opportunities to show others that I am becoming an adult and can act responsibly" and "I have opportunities to develop skills that will be useful later in life" on the Individual - Social Skills dimension, and related to the Context dimension, more specifically its Cultural component, "I have people I look up to" and "I think it is important to serve my community".

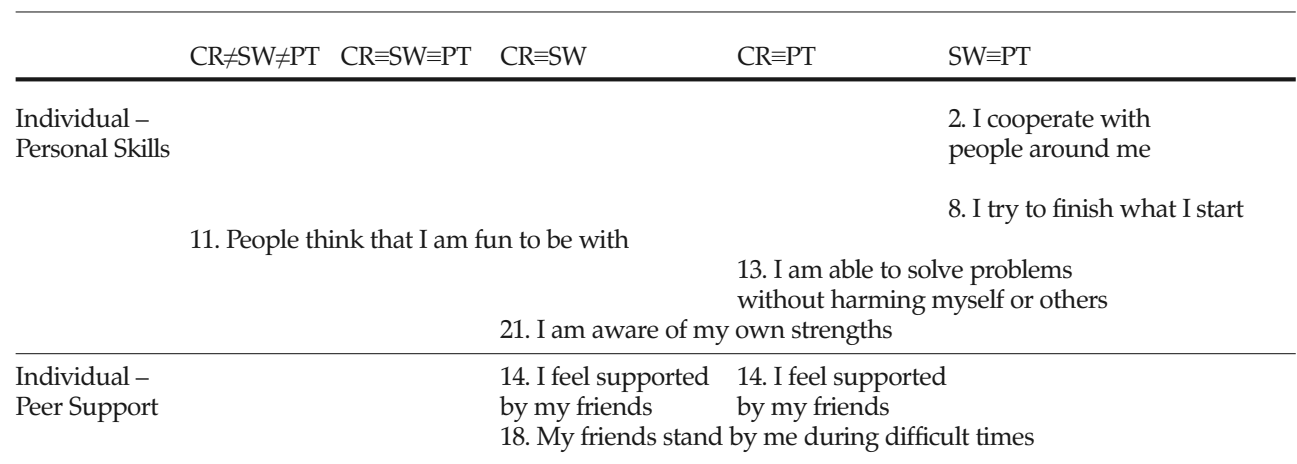

\begin{tabular}{ll}
\hline Individual - & $\begin{array}{l}\text { 4. I know how to behave in } \\
\text { different social situations }\end{array}$
\end{tabular}

20. I have opportunities to show others that I am becoming

15. I know where to go in my community to get help

an adult and can act responsibly

25. I have opportunities to develop skills that will be useful later in life

$\begin{array}{ll}\text { Caregiver - } & \text { 5. My parent(s)/caregiver(s) } \\ \text { Physical giving } & \text { watch me closely }\end{array}$

7. If I am hungry, 7. If I am hungry, there is enough there is enough to eat to eat

\begin{tabular}{lc}
\hline $\begin{array}{l}\text { Caregiver - } \\
\text { Psychological }\end{array}$ & $\begin{array}{l}\text { 6. My parent(s)/care- } \\
\text { giver(s) know } \\
\text { Caregiving }\end{array}$ \\
& a lot about me
\end{tabular}

26. I enjoy my family's/caregiver's cultural and family traditions giver(s) know a lot about me
6. My parent(s)/care-

24. I feel safe when I am with my family/caregiver(s)

o serve my community

\begin{tabular}{ll}
\hline $\begin{array}{l}\text { Context - } \\
\text { Spiritual }\end{array}$ & 23. I think it is important to serve my community \\
\hline $\begin{array}{l}\text { Context - } \\
\text { Education }\end{array}$ & $\begin{array}{l}\text { 3. Getting an education is } \\
\text { important to me }\end{array}$ \\
\hline $\begin{array}{l}\text { Context - } \\
\text { Cultural }\end{array}$ & $\begin{array}{l}\text { 1. I have people I look up to } \\
\text { 19. I am treated fairly in my community }\end{array}$
\end{tabular}

27. I enjoy my community's traditions
3. Getting an education is important to me 16. I feel I belong at my school

CR - Croatia; SW - Sweden; PT - Portugal; $\neq$ - Mean differences between the three countries that are statistically significant $(p<0.05)$; $\equiv-$ Mean differences between countries that are statistically non-significant $(p>0.05)$. 
DRUŠ. ISTRAŽ. ZAGREB GOD. 29 (2020), BR. 4, STR. 555-574

MILJEVIĆ-RIĐIČKI, R. ET AL.:

RESILIENCE IN SCHOOL...
Table 4 presents the differences and similarities between the three countries. The three countries do not differ between each other on only three items: one related to Physical Caregiving ("My parent(s)/caregiver(s) watch me closely"), and two related to Psychological Caregiving ("I talk to my family/caregiver(s) about how I feel", and "My family stands by me during difficult times"). For all the other 21 items there were verifiable differences and similarities between the three countries, as indicated by the post-hoc comparisons using the Scheffe or Dunnett T3 test (for items with equal variances assumed or not assumed, respectively). Considering the CYRM dimensions, the items related to Social Skills were the ones where more differences were verified between the three countries (in three items from a total of four). Differences between all three countries were also found for one item related to personal skills ("People think that I am fun to be with") and another to spiritual context ("I think it is important to serve my community"). Nevertheless, similarities between the countries were also found between pairs of countries. Sweden and Portugal share the greatest number of non-significant comparisons (on nine items, Sweden and Portugal do not present statistically significant differences of means), followed by Croatia and Sweden (on eight items). Croatia and Portugal have the fewest similarities in the country-pair comparisons (on only three items there is no statistically significant difference between Croatia and Portugal).

\section{DISCUSSION}

The results show that, in general, the Resilience total score (obtained on the CYRM Global scale) for the three countries is high (above 100, with a maximum of 120). Nevertheless, differences can be found between the countries, especially between Croatia and Portugal (on the CYRM Global scale, and the Individual and Caregiver scales). The Context subscale was the only one where differences between the three countries were found, which probably reflects the differences between the contexts/cultures where the study was conducted: central, northern and southern Europe. As pointed out by several authors in the field, coping patterns and resilience are context-sensitive (Kuo, 2010; Ungar, 2008). scores for the 24 resilience items are high. The lowest mean (Table 1) is 3.54 (on the scale 1-5) for Portugal for the item "I have people I look up to", but most of the means (for all 3 countries) are higher than 4.00. For Sweden, all the means are between 4 and 5 . This is in line with numerous international research findings on youth life satisfaction; most children re-
For the items analysis, the results show that, overall, the 
DRUŠ. ISTRAŽ. ZAGREB GOD. 29 (2020), BR. 4, STR. 555-574

MILJEVIĆ-RIĐIČKI, R. ET AL.:

RESILIENCE IN SCHOOL... port positive life satisfaction (Proctor et al., 2009; Maurović, 2015). The descriptive statistics (Table 1) show that Sweden has the highest mean for 9 (out of 24) items, while Croatia has the highest mean for 15 items.

Comparisons between the three countries show differences with a medium effect size for seven items: for the subscale Individual - Personal Skills, Croatia presents the highest means on two items ("I cooperate with people around me" and "I am aware of my strengths"); for the Individual - Social Skills subscale, Croatia presents the highest means on three items ("I know how to behave in different situations", "I have opportunities to show others that I am becoming an adult and act responsibly", and "I have opportunities to develop skills that will be useful later in life"); for the Context Cultural subscale, Sweden presents the highest mean for the item "I have people I look up to"; and finally, for the Context - Spiritual subscale, the country with the highest mean for the single item tested, "I think it is important to serve my community", is Croatia. Similarities between the three countries are found in the items which describe the relationship with primary caregiver and peer support. There are more similarities between Sweden and Portugal (8 items) and Sweden and Croatia (6 items) than between Croatia and Portugal (3 items) (calculated from the data in Table 2).

In recent years, significant changes have taken place in Europe, including the countries under analysis in this study. In Sweden, the number of immigrants has increased, which is likely to have affected the school population. In some of the classes investigated there are only one or two children with parents born in Sweden. Portugal has had significant economic crises in recent years and their impact on the health and well-being of young people is well known (Frasquilho et al., 2016). For instance, a study by Frasquilho (2017) showed that young people living with unemployed parents report significantly poorer mental well-being outcomes (sadness, worry and bad temper), changes in family relations and lower future educational expectations, than those living with employed parents. This study also points to some of the main aspects of vulnerability, namely being a younger child, having paternal unemployment, and being in a low socioeconomic position. These aspects are reflected in the Portuguese sample since a significant part of the data was collected in schools with migrant and/or refugee pupils. Their schools are generally located in more deprived areas, where risk factors tend to accumulate and impact negatively on resilience levels and thereby on mental health outcomes. In the European Social Survey concerned with flourishing (which includes resilience), Portugal showed the lowest overall rate of "flourish- 
DRUŠ. ISTRAŽ. ZAGREB GOD. 29 (2020), BR. 4, STR. 555-574

MILJEVIĆ-RIĐIČKI, R. ET AL.:

RESILIENCE IN SCHOOL... ing" people among 22 countries. Sweden was 7th (Huppert \& So, 2013).

As mentioned above, Croatia stands out as being the "youngest country" - since it dates from when former Yugoslavia broke up and Croatia became an independent state (in 1991). Having a country of their own meant a lot to Croatian people. Community identity may still differentiate between the countries, especially in a Contextual - Spiritual context (consider the item "I think it is important to serve my community"). After 1991, when Croatia became a new, independent state, and 2013, when it became a member of the EU, the country was opened up to a lot of educational and other influences from abroad. Among other educational programs, resilience was introduced into Croatian educational society.

Social and emotional learning (SEL) interventions have shown results all over the world (Taylor et al., 2017), and follow-ups show positive health outcomes (Jones et al., 2015). The theoretical foundations and principles of SEL interventions have inspired the development of a Resilience Curriculum (RESCUR) for Europe, which has been developed by six European universities (in Malta, Msida - project leader, Crete, Lisbon, Pavia, Zagreb, and Örebro) (Cefai, Miljević-Riđički et al., 2015).

The curriculum is designed for implementation in preschools and schools. However, Europe is a multicultural diverse society and will become even more so given current immigration. Even though the curriculum was written for the whole of Europe, it may not be needed everywhere, and some countries may need it or parts of it more than others. While working on RESCUR, the authors of this article noticed that countries differ in orientation to particular themes and activities in kindergartens and schools. For example, in Croatian kindergartens there is good coverage of activities that improve communication skills, but they lack activities that promote problem-solving and some other topics. Portuguese colleagues have introduced self-determination development to the curriculum, and Swedish colleagues building-on-strengths.

Our findings should be interpreted within the limitations of this study. The study depends on the operational validity of the Child and Youth Resilience Measure (CYRM), which has been widely assessed but is not further discussed here. An important limitation is that some resilience items from the Context subscale were excluded in the Swedish data: two of the three Spiritual items, and two out of five of the Cultural items. This means that almost half of the items on the Context subscale were not considered by members of 
DRUŠ. ISTRAŽ. ZAGREB GOD. 29 (2020), BR. 4, STR. 555-574

MILJEVIĆ-RIĐIČKI, R. ET AL.:

RESILIENCE IN SCHOOL... the Swedish subsample. It is an important weakness since it affects the Context scale score as well as the CYRM Global scale score. These items were excluded because, in a previous study where this instrument was used, it was found that Swedish children did not understand and could not relate to them. Since one of the Swedish aims was to compare their data with the data in that study, they deleted the same items as had been deleted in the previous study. For the current sample, however, it was probably a mistake not to include these items, particularly since $15 \%$ of the Swedish children's parents had a foreign background compared to $9 \%$ in the population as a whole; accordingly, the items could have made a difference. This aspect of the sample distribution can also be a limitation given our intention to make comparisons between the different countries, since it impacts the sample's representativeness.

As such, our results must be interpreted with caution bearing in mind the limitations presented. The goals of the present study were to contribute to comparing children's resilience in the three countries and reflect on intervention needs in the field. The relative homogeneity of the item scores suggests that there is a case for a Europe-wide resilience curriculum (RESCUR). However, the analysis also suggests that there are differences in the scores that might justify the tailoring of the curriculum to local conditions. Teachers from the different countries may be best placed to decide which themes to work with, by considering their relevance to their particular groups. Accordingly, it might be useful to develop recommendations for different types of countries, depending, for example, on their level of development or country-specific cultural dimensions, like social skills. Recent changes in European countries are likely to have influenced the results, which may be why Sweden was found not to differ from Portugal and Croatia as much as expected.

\section{REFERENCES}

Bronfenbrenner, U. (1986). Ecology of the family as a context for human development: Research perspectives. Developmental Psychology, 22(6), 723-742. https://doi.org/10.1037//0012-1649.22.6.723

Cefai, C., Cavioni, V., Bartolo, P., Simões, C., Miljevic-Ridicki, R., Bouilet, D., Pavin Ivanec, T., Matsopoulos, A., Gavogiannaki, M., Zanetti, M. A., Galea, K., Lebre, P., Kimber, B., \& Eriksson, C. (2015). Social inclusion and social justice: A resilience curriculum for early years and elementary schools in Europe. Journal for Multicultural Education, 9(3), 122-139. https://doi.org/10.1108/jme-01-2015-0002

Cefai, C., Miljević-Riđički, R., Bouillet, D., Pavin Ivanec, T., Milanović, M., Matsopoulos, A., Gavogiannaki, M., Zanetti, M. A., Ca- 
DRUŠ. ISTRAŽ. ZAGREB GOD. 29 (2020), BR. 4, STR. 555-574

MILJEVIĆ-RIĐIČKI, R. ET AL.:

RESILIENCE IN SCHOOL... vioni, V., Bartolo, P., Galea, K., Simoes, C., Lebre, P., Caetano Santos, A., Kimber, B., \& Erikson, C. (2015). RESCUR: Surfing the waves. A resilience curriculum for early years and primary schools - A teacher's guide. Centre for Resilience and Socio-Emotional Health, University of Malta.

Chen, S. X., Cheung, F. M., Harris Bond, M., \& Leung, J. P. (2005). Decomposing the construct of ambivalence over emotional expression in a Chinese cultural context. European Journal of Personality, 19(3), 185-204. https://doi.org/10.1002/per.538

Durlak, J. A., Weissberg, R. P., Dymnicki, A. B., Taylor, R. D., \& Schellinger, K. B. (2011). The impact of enhancing students' social and emotional learning: A meta-analysis of school-based universal interventions. Child Development, 82(1), 405-432. https://doi.org/10. 1111/j.1467-8624.2010.01564.x

Eriksson, C., Kimber, B., \& Skoog, T. (2018). Design and implementation of RESCUR in Sweden for promoting resilience in children: A study protocol. BMC Public Health, 18(1). https://doi.org/10.1186/s128 89-018-6145-7

Estevão, P., Calado, A., \& Capucha, L. (2017). RESILIENCE Moving from a "heroic" notion to a sociological concept. Sociologia, Problemas e Práticas, (85), 9-25. https://doi.org/10.7458/SPP20178510115

Ferreira, L. (2014). Associações entre a Resiliência, a Autocompaixão e a Orientação Temporal na adolescência [Associations between resilience and self-compassion and temporal orientation in adolescence] (Master Thesis). Universidade de Coimbra. https://core.ac.uk/reader/43579560

Frasquilho, D. (2017). Mental health, employment status and parenthood: The impact of the economic downturn on Portuguese youth mental health. (Doctoral Thesis). Nova Medical School, Lisbon.

Frasquilho, D., de Matos, M. G., Gaspar, T., \& Caldas de Almeida, J. M. (2016). Young people's well-being and the economic crisis: How does parental unemployment and family wealth affect the downturn experience? Children and Youth Services Review, 69, 219-222. https://doi. org/10.1016/j.childyouth.2016.08.018

Graber, J. A., \& Brooks-Gunn, J. (1996). Transition and turning points: Navigating the passage from childhood to adolescence. Developmental Psychology, 32(4), 768-776. https://doi.org/10.1037/0012-1649.32.4.768

Helliwell, J., Layard, R., \& Sachs, J. (2018). World happiness report 2018. Sustainable Development Solutions Network.

Huppert, F. A., \& So, T. T. C. (2013). Flourishing across Europe: Application of a new conceptual framework for defining well-being. Social Indicators Research, 110(3), 837-861. https://doi.org/10.1007/s11 205-011-9966-7

International Monetary Fund (2018). World economic outlook: Challenges to steady growth. Washington DC, October.

Jones, D. E., Greenberg, M., \& Crowley, M. (2015). Early social-emotional functioning and public health: The relationship between kindergarten social competence and future wellness. American Journal of Public Health, 105(11), 2283-2290. https://doi.org/10.2105/AJPH.2015. 302630 
DRUŠ. ISTRAŽ. ZAGREB GOD. 29 (2020), BR. 4, STR. 555-574

MILJEVIĆ-RIĐIČKI, R. ET AL.:

RESILIENCE IN SCHOOL..
Kolar, K. (2011). Resilience: Revisiting the concept and its utility for social research. International Journal of Mental Health Addiction, 9, 421-433. https://doi.org/10.1007/s11469-011-9329-2

Kuo, B. C. H. (2010). Culture's consequences on coping: Theories, evidences, and dimensionalities. Journal of Cross-Cultural Psychology, 42(6), 1084-1100. https://doi.org/10.1177/0022022110381126

Lahad, S. (1993). Tracing coping resources through a story in six parts - The 'BASIC-Ph' model. In Psychology at school and the community during peaceful and emergency times (pp. 55-70). Levinson-Hadar.

Liebenberg, L., Ungar, M., \& de Vijver, F. V. (2012). Validation of the Child and Youth Resilience Measure-28 (CYRM-28) among Canadian youth. Research on Social Work Practice, 22(2), 219-226. https://doi.org/ 10.1177/1049731511428619

Masten, A. S. (2011). Resilience in children threatened by extreme adversity: Frameworks for research, practice, and transnational synergy. Development and Psychopathology, 23(2), 493-506. https://doi.org/ 10.1017/S0954579411000198

Maurović, I. (2015). Otpornost adolescenata u dječjim domovima [The resilience of adolescents in children's homes]. (Doctoral thesis). Faculty of Law, Study Center for Social Work, University of Zagreb.

Park, R. D., \& Gauvain, M. (2009). Child psychology: A contemporary viewpoint (7th Ed.). McGraw-Hill.

Proctor, C., Linley, P., \& Maltby, J. (2009). Youth life satisfaction: A review of the literature. Journal of Happiness Studies, 10(5), 583-630. https:// doi.org/10.1007/s10902-008-9110-9

Ravlić, S. (Ed.) (2019). Hrvatska enciklopedija [Croatian Encyclopaedia]. Leksikografski zavod Miroslav Krleža.

Sun, J., \& Stewart, D. (2007). Age and gender effects on resilience in children and adolescents. International Journal of Mental Health Promotion, 9(4), 16-25. https://doi.org/10.1080/14623730.2007.9721845

Taylor, R. D., Oberle, E., Durlak, J. A., \& Weissberg, R. P. (2017). Promoting positive youth development through school-based social and emotional learning interventions: A meta-analysis of follow-up effects. Child Development, 88(4), 1156-1171. https://doi.org/10.1111/cdev. 12864

Ungar, M. (2008). Resilience across cultures. The British Journal of Social Work, 38(2), 218-235. https://doi.org/10.1093/bjsw/bcl343

Ungar, M., \& Liebenberg, L. (2011). Assessing resilience across cultures using mixed methods: Construction of the child and youth resilience measure. Journal of Mixed Methods Research, 5(2), 126-149. https://doi. org/10.1177/1558689811400607

United Nations (2017). International migration report 2017: Highlights (ST/ESA/SER.A/404). Department of Economic and Social Affairs, Population Division. 
DRUŠ. ISTRAŽ. ZAGREB

GOD. 29 (2020), BR. 4, STR. 555-574

MILJEVIĆ-RIĐIČKI, R.

ET AL.:

RESILIENCE IN SCHOOL...

\section{Otpornost školske djece - multikulturna usporedba triju zemalja - Hrvatske, Svedske i Portugala}

Renata MILJEVIĆ-RIĐIČKI

Sveučilište u Zagrebu, Učiteljski fakultet, Zagreb, Hrvatska

Celeste SIMÕES

Sveučilište u Lisabonu, Kineziološki fakultet, Cruz Quebrada,

Portugal

Birgitta KIMBER

Sveučilište Umeå, Odsjek za kliničke znanosti, Umeå, Švedska

Kultura i kontekst važni su za diečji razvoj te utječu, između ostalog, i na otpornost. Glavni cili našeg istraživanja bio je provjeriti postoje li razlike u otpornosti školske djece od 10 do 12 godina između triju zemalja - Hrvatske, Švedske i Portugala. Ispitanici su bili učenici ( $N=750)$ iz hrvatskih, švedskih i portugalskih škola, 54,5 \% dječaka i 45,5\% djevojčica. Primijenjen je upitnik otpornosti Child and Youth Resilience Measure, CYRM-28. Provedene su deskriptivna analiza podataka i jednosmierna analiza varijance. Ukupan rezultat, kao i rezultati na pojedinim česticama CYRM-28, visoki su. Nađene su i razlike i sličnosti između triju zemalja. Švedska i Portugal imaju najviše sličnosti, a zatim Hrvatska i Švedska. Hrvatska i Portugal imaju najmanje sličnosti kad se gledaju parovi zemalja. O rezultatima se raspravlja u kontekstu potreba zemalja za obrazovanjem za otpornost i primienom kurikula otpornosti.

Ključne riječi: djeca, otpornost, međukulturna usporedba, kurikul otpornosti

\section{c) (1) \$}

Međunarodna licenca / International License:

Imenovanje-Nekomercijalno / Attribution-NonCommercial 